Brit. J. vener. Dis. (1955), 31, 160.

\title{
BENZATHINE PENICILLIN IN THE MANAGEMENT OF THE TREPONEMATOSES * $\dagger$
}

\author{
BY \\ T. GUTHE \\ Venereal Disease and Treponematoses Section, Division of Communicable Disease Services, \\ World Health Organization, Geneva
}

\section{INTRODUCTION}

Twelve years ago investigators of the Liverpool School of Tropical Medicine (1943) and Lourie and Collier (1943) showed the effectiveness of penicillin in spirochaetosis, and staff members of the United States Public Health Service (Mahoney, Arnold, and Harris, 1943) demonstrated the curative power of this antibiotic in venereal syphilis. Experience with penicillin has since accumulated impressively

* Received for publication April 19, 1955.

+ Presented, by invitation, to the Medical Society for the Study of Venereal Diseases. January $28,1955$. and the decade following the second World War became one of complete reorientation in the management of venereal syphilis and of the nonvenereal, endemic treponematoses, highly prevalent in many underdeveloped rural areas of the world.

Five years ago I had the privilege of speaking to the Medical Society for the Study of Venereal Diseases on the treponematoses-syphilis, yaws, and pinta-as a world problem. The doubts about the curative effectiveness of penicillin alone as an antisyphilitic drug were then perhaps only beginning to be dispelled in Britain, while in many other

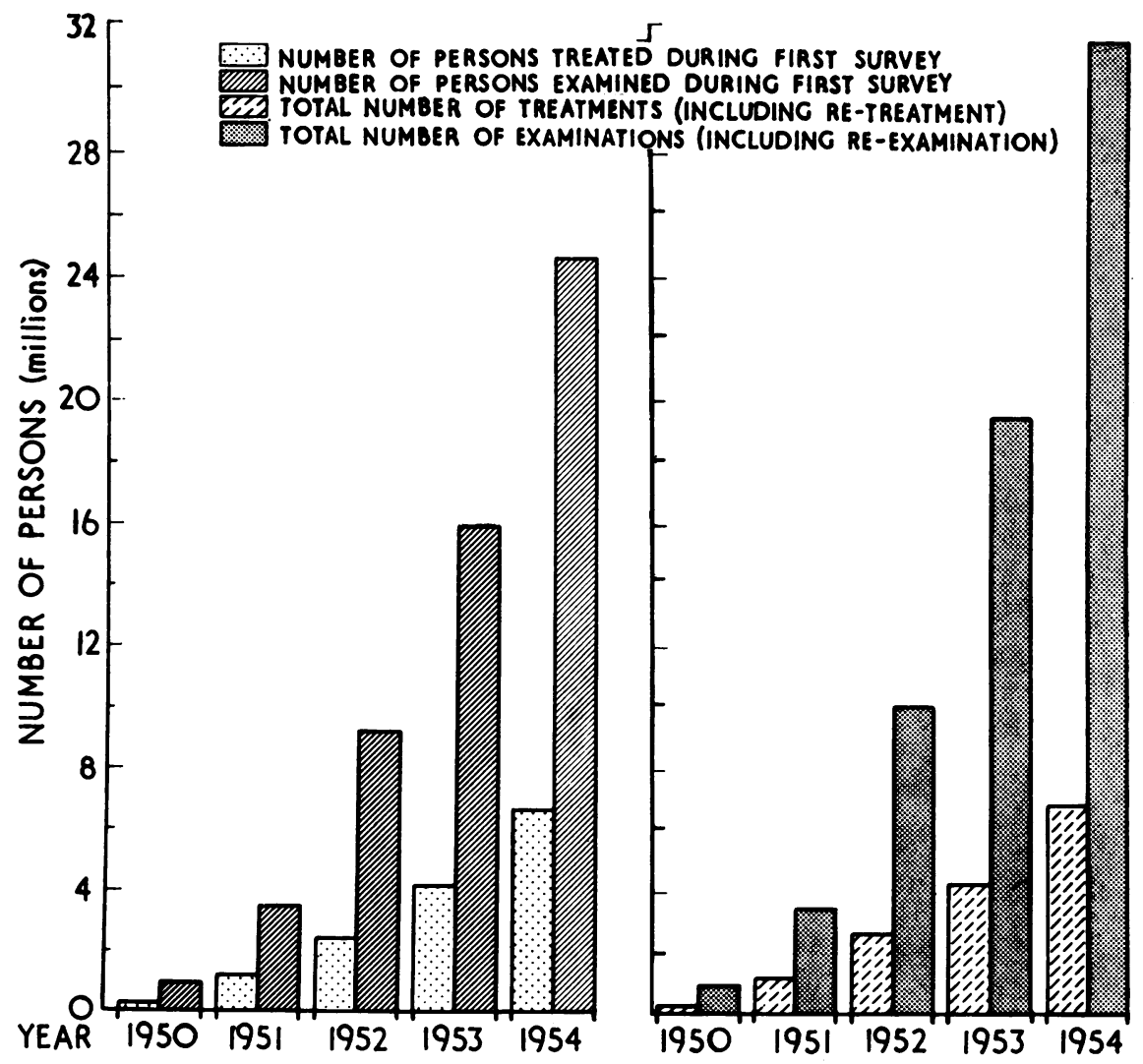

FIG. 1.-Total number of persons examined and treated for treponemal diseases in mass campaigns, $1950-54$. 
countries medical workers, taking a more traditional attitude, were relying solely on their past experience with metal chemotherapy. To-day the outlook has changed practically everywhere, and penicillin alone has become the drug of choice throughout the world. This is illustrated by an international study undertaken by WHO in 1953 in which some 70 per cent. of 277 leading clinics of dermato-venereology in 55 countries were reported to be using penicillin alone in the treatment of early syphilis (Willcox, Guthe, Idsoe, and Reynolds, 1954). Furthermore, there is increasing evidence that penicillin is gradually being used as the sole treatment for all forms of the disease, including the latent and late systemic stages. Another noteworthy trend has been the tendency to draw conclusions on the long-term curative value of penicillin in the treponematoses after a much shorter period than would have been possible in the era of metal chemotherapy. According to classical criteria, a patient adequately treated for early syphilis with metals and showing negative blood and cerebrospinal fluid tests after 4 years had every reason to consider himself permanently cured. To-day, an increasing number of investigators are prepared to consider a patient cured after only 2 years' observation. This attitude is undoubtedly based on the fact that most of the true penicillin failures in the treatment of the early infection occur within 6 to 9 months of treatment and are very seldom observed after 2 years. Furthermore, long-term observations have shown that late involvements of the cardiovascular and nervous systems are apparently very rare indeed after penicillin therapy.

From the public health point of view penicillin has demonstrated its great value as an inexpensive weapon in combating the endemic treponematoses on a large scale. This is particularly true of yaws, which is highly prevalent in the tropics. Five years ago internationally aided mass campaigns against the treponematoses were only just beginning, but they have since developed into going concerns (see Figs 1 and 2) and many have become precursors of broad, long-term, health programmes.

Finally, on the laboratory side the Treponema pallidum immobilization (TPI) technique has become a useful diagnostic tool, and the $T$. pallidum agglutination (TPA) test is now being similarly developed. It is a paradox that these tests, which are required for much-needed study of the nature of the immunity phenomena, have only become available at a time when the main interest of the clinician is to apply an intensive form of treatment with penicillin, the immediate effect of which is to bring about the destruction of the treponemes regardless of concomitant immunity processes. Quantitative standardization of conventional serological tests for the treponematoses has also become possible through the establishment of international cardiolipin and lecithin reference preparations, as well as of

\begin{tabular}{|c|c|c|}
\hline & Laos & Laos \\
\hline Paraguay & Paraguay & Paraguay \\
\hline India III & India III & India III \\
\hline Philippines & Philippines & Philippines \\
\hline Ecuador II & Ecuador II & Ecuador II \\
\hline Iraq & Iraq & Iraq \\
\hline Thailand & Thailand & Thailand \\
\hline Haiti & Haiti & Haiti \\
\hline Indonesia & Indonesia & Indonesia \\
\hline Yugoslavia & Yugoslavia & Yugoslavia \\
\hline GUATEMALA & TAIWAN & TAIWAN \\
\hline ROTTERDAM & GUATEMALA & GUATEMALA \\
\hline S. ARABIA & ROTTERDAM & ROTTERDAM \\
\hline PAKISTAN I & S. ARABIA & S. ARABIA \\
\hline IRAN & PAKISTAN I & PAKISTAN I \\
\hline INDIA II & IRAN & IRAN \\
\hline ETHIOPIA & INDIA II & INDIA II \\
\hline BURMA & ETHIOPIA & ETHIOPIA \\
\hline CEYLON & BURMA & BURMA \\
\hline EGYPT & CEYLON & CEYLON \\
\hline AFGHANISTAN & AFGHANISTAN & AFGHANISTAN \\
\hline 1952 & 1953 & 1954 \\
\hline
\end{tabular}

FIG. 2.-TREPONEMATOSIS-CONTROL PROJECTS ASSISTED BY WHO AND UNICEF, $1948-54$. Countries printed in small capitals denote demonstration and training projects; countries printed in italics denote mass campaigns; roman numerals indicate more than one project in the same country. 
freeze-dried reference sera at different levels of reactivity. These are now available at the WHO International Serological Reference Laboratory at the State Serum Institute in Copenhagen, which will distribute them on request to national V.D. laboratories in many countries. At the same time, preliminary information has been accumulating, leading to the definition of certain biochemical characteristics of the treponemes as well as of the influence of certain physical factors in the host environment-particularly in regard to the hyaluronic acid/hyaluronidase system - and the influence of endogenous temperatures in the body on the selective localization of lesions in different tissues and systems. These studies, many of which have been carried out at the WHO International Treponematosis Laboratory Center,* suggest new and promising approaches to the ultimate solution of the riddle of the inter-relationship of the treponematoses.

\section{PENICILLIN IN THE MANAGEMENT OF THE}

\section{TREPONEMATOSES}

The penicillin preparation which has gradually become accepted in individual and clinical practice as well as in mass campaigns is PAM (procaine penicillin $G$ in oil with 2 per cent. aluminium monostearate), introduced by Buckwalter and Dickinson (1948). In spite of its recognized advantages some limitations have been ascribed to this preparation, particularly in individual and clinical practice in the more highly developed countries. First, side-effects are apparently more frequent than was previously observed; these are referred to later. Secondly, the injection of initial, large " insurance" dosages of 1.2 or 2.4 mega units and "single session" treatments with total doses of 4.8-6.0 mega units have meant injection into several depot sites and have, in the case of large doses, tended to cause local discomfort and complaints of a " lumpy" feeling. Thirdly, PAM has been found to vary in quality, so that the duration of the penicillinaemia - and therefore of the curative effect-may differ not only from one product to another, but also between different batches from one manufacturer. This aspect is further complicated by the fact that laboratory experts have been unable to agree on the reliability of suitable standard methods for the assay of penicillin in blood and tissues.

The existence on the international market of substandard preparations of PAM led WHO to establish certain minimum requirements in 1950 . Steps have recently been taken by the WHO Expert Committee

* Johns Hopkins University School of Hygiene and Public Health, Baltimore, Md, U.S.A. on Biological Standardization to revise these requirements, and an International Reference Preparation of PAM, against which manufacturers will be able to check their products, is envisaged. An improved method, using rabbits rather than humans, is also to be developed for the assay of blood concentration resulting from any repository penicillin. These developments are the result of cooperation between the United Kingdom and WHO.

\section{Penicillin Salts}

During recent years the antibiotic properties of a number of new penicillin salts have been investigated. Some salts have been under clinical trial for some time, in an attempt to find derivatives which might cause fewer sensitization reactions, for example, the so-called " hypo-allergic" penicillins, such as allylmercaptomethyl penicillin (penicillin O) (Weiss and Wright, 1953) and phenyltoloxamine penicillin (Granatek, Gottstein, and Cheney, 1954). Others have been developed in a search for preparations with repository effect which might obviate the use of procaine or oily components, e.g., benethamine penicillin, which appears to possess properties very similar to procaine penicillin ; and penicillin $G$ diethylamino-ethylester hydriodide ("Neopenil"), which has produced cerebrospinal fluid concentrations ten times as high as other penicillins (Schimmel, Wilson, Matteucci, and Flippin, 1952). The most important development, however, has been the introduction of $N, N^{\prime}$-dibenzylethylenediamine dipenicillin $\mathrm{G}$, known as benzathine penicillin $G,{ }^{*}$ first described by Szabo and others (1951). Studies of its properties have been carried out by Elias, Price, and Merrion (1951), Lepper, Rodriguez, Blatt, and Spies (1952), Seifter, Glassman, Begany, Ehrich, and Beckfield (1954), and others. This procaine-free, slowly absorbed, amino-salt of penicillin $G$ has low toxicity, few side-reactions, and a penicillinaemia of long duration, whether administered orally or intramuscularly. In addition, there is the obvious advantage that the oily vehicle used in the repository PAM preparations can be dispensed with in parenteral benzathine preparations.

Curative Aspects.-A number of reports have been published on the therapeutic use of benzathine penicillin in various infections. These are summarized in Table I (opposite), which also shows the considerable interest that exists concerning the treatment of treponematoses, which is demonstrated by the number of clinical trials in syphilis, yaws, and pinta under way in different countries, in many

\footnotetext{
* Trade names : Tardocillin, Extencilline, Scurocillin, Duropenin,
} Penidural, Bicillin, Capacilina, Wycillina, and others. 
instances as part of the activities of an international cooperative group established by WHO.

Since "the major determinant factor in the therapeutic activity in penicillin is the aggregate time ... for which the drug remains at bactericidal levels" (Eagle, Fleischman, and Musselman, 1950), it is of primary interest to compare the penicillinaemia obtainable with benzathine penicillin $G$ with that obtainable with PAM. This is illustrated in Fig. 3 (overleaf), showing the penicillinaemia curves of the two repository preparations following several schedules. Curves are also included for "Panbiotic" or "all-purpose penicillin"-a triple combination of potassium ( 0.3 mega units), procaine $(0.3$ mega units), and benzathine penicillin $\mathrm{G}$ ( $0.6 \mathrm{mega}$ units) investigated by Rein, Buckwalter, Mann, Landy, and Flax (1953), and for benzathine penicillin $G$ in oil with aluminium monostearate (BOM).

These are average values of units of penicillin per $\mathrm{ml}$. serum, as determined by the standard

TABLE I

USE OF BENZATHINE PENICILLIN G IN VARIOUS INFECTIONS

\begin{tabular}{|c|c|c|c|c|c|}
\hline \multirow{2}{*}{ Condition } & \multicolumn{2}{|c|}{ Benzathine Penicillin $\mathbf{G}$} & \multirow{2}{*}{ Author } & \multirow{2}{*}{ Date } & \multirow{2}{*}{ Patient Series } \\
\hline & Oral (units) & Parenteral (units) & & & \\
\hline $\begin{array}{l}\text { Mixed pulmonary infec- } \\
\text { tions }\end{array}$ & 250,000 and 500,000 & - & Lepper and others & 1952 & 32 children \\
\hline Gonorrhoea & 一 & $\begin{array}{c}300,000, \\
\text { mega }\end{array}$ & O'Brien and Smith & 1952 & 396 cases \\
\hline Rheumatic fever & - & 600,000 repeated & Stollerman and Rusoff & 1952 & 135 children \\
\hline $\begin{array}{l}\text { Group B streptococcal } \\
\text { infections }\end{array}$ & $\begin{array}{l}\text { (Also peroral indica- } \\
\text { tion in some cases) }\end{array}$ & $600,000-1,000,000$ & Breese & 1953 & $\begin{array}{l}1,204 \text { infections in } 793 \\
\text { children }\end{array}$ \\
\hline Scarlet fever & $\begin{array}{l}7,000 \text { and } 13,000 \text { per } \\
\mathrm{kg} \text {. body weight }\end{array}$ & 一 & $\begin{array}{l}\text { Coriell, } \\
\text { Preston, and Hunt }\end{array}$ & 1953 & $\begin{array}{l}38 \text { children, of whom } \\
\text { eleven had other } \\
\text { throat infections }\end{array}$ \\
\hline $\begin{array}{l}\text { Pneumococcus pneumonia } \\
\text { and Group B strepto- } \\
\text { coccus }\end{array}$ & $\begin{array}{l}600,000 \text { initially fol- } \\
\text { lowed by } 300,000 \\
\text { every } 8 \text { hours for a } \\
\text { minimum of } 4 \text { days }\end{array}$ & - & Finberg and others & 1953 & 63 children \\
\hline "Volunteers" & - & 600,000 & Fletcher and Knappett & 1953 & 19 males \\
\hline Otitis & $\longrightarrow$ & $\begin{array}{l}49 \text { patients - } 600,000 \\
\text { benzathine penicillin } \mathrm{G} \\
\text { preceded by or simul- } \\
\text { taneously with } 300,000 \\
\text { procaine penicillin } \mathrm{G} \\
\text { in one injection } \\
51 \text { patients - } 600,000 \\
\text { benzathine penicillin } \\
\mathrm{G} \text { alone }\end{array}$ & Walker & 1954 & $\begin{array}{l}100 \text { infants and } \\
\text { children }\end{array}$ \\
\hline $\begin{array}{l}\text { Pneumococcus } \\
\text { pneumonia }\end{array}$ & - & $\begin{array}{lr}\text { (a) } & 1,200,000 \\
\text { (b) } & 600,000\end{array}$ & Walker and Hamburger & 1954 & $\begin{array}{l}\text { (a) } 30 \text { cases } \\
\text { (b) } 19 \text { cases }\end{array}$ \\
\hline Pinta & - & "Panbiotic" 2.4 mega & $\begin{array}{l}\text { Marques, Mexico (quoted } \\
\text { by Rein and Mann) }\end{array}$ & 1954 & 92 cases \\
\hline Yaws & - & $0.6-1.2 \mathrm{mega}$ & Grin and others, Thailand & 1954 & 236 cases \\
\hline Yaws & - & $\begin{array}{l}\text { "Panbiotic", } \\
1.2 \text { mega (adults) } \\
0.6 \text { mega (children) }\end{array}$ & $\begin{array}{l}\text { Hill, Jamaica (quoted by } \\
\text { Rein and Mann) }\end{array}$ & 1954 & 336 cases \\
\hline Syphilis in adults & - & $2 \cdot 5$ mega & Shafer and Smith, U.S.A. & 1954 & 196 cases \\
\hline Syphilis in adults & - & $2 \cdot 4-2.5$ mega & Smith and others, U.S.A. & 1954 & 127 cases \\
\hline Syphilis in adults & - & 2.4 mega & $\begin{array}{l}\text { Vilanova and Alvarado, } \\
\text { Spain }\end{array}$ & 1954 & 81 cases \\
\hline Syphilis & - & $\begin{array}{l}\text { "Panbiotic" } \\
1.2 \text { mega and } 2.4 \text { mega }\end{array}$ & $\begin{array}{l}\text { Ribas, U.S.A. (quoted by } \\
\text { Rein and Mann) }\end{array}$ & 1954 & 132 cases \\
\hline Syphilis in pregnancy & - & $1 \cdot 2-2 \cdot 4$ mega & Idsoe, Taiwan & $1954^{*}$ & 48 cases \\
\hline Syphilis in pregnancy & - & 2.4 mega & Shafer and Smith, U.S.A. & 1954 & 8 cases \\
\hline Early syphilis & - & $1 \cdot 2-2 \cdot 4 \mathrm{mega}$ & $\begin{array}{c}\text { International Co-opera- } \\
\text { tive Clinical Group }+\end{array}$ & - & 238 cases \\
\hline
\end{tabular}

* Communication to WHO.

† Barros (Brazil), British Clinical Co-operative Group (U.K.), Chaglassian (Lebanon), Christiansen (Iran), Danbolt (Norway), Gay (Spain), Hellerström (Sweden), Putkonen (Finland), Ragab (Egypt), and Rajam (India). 

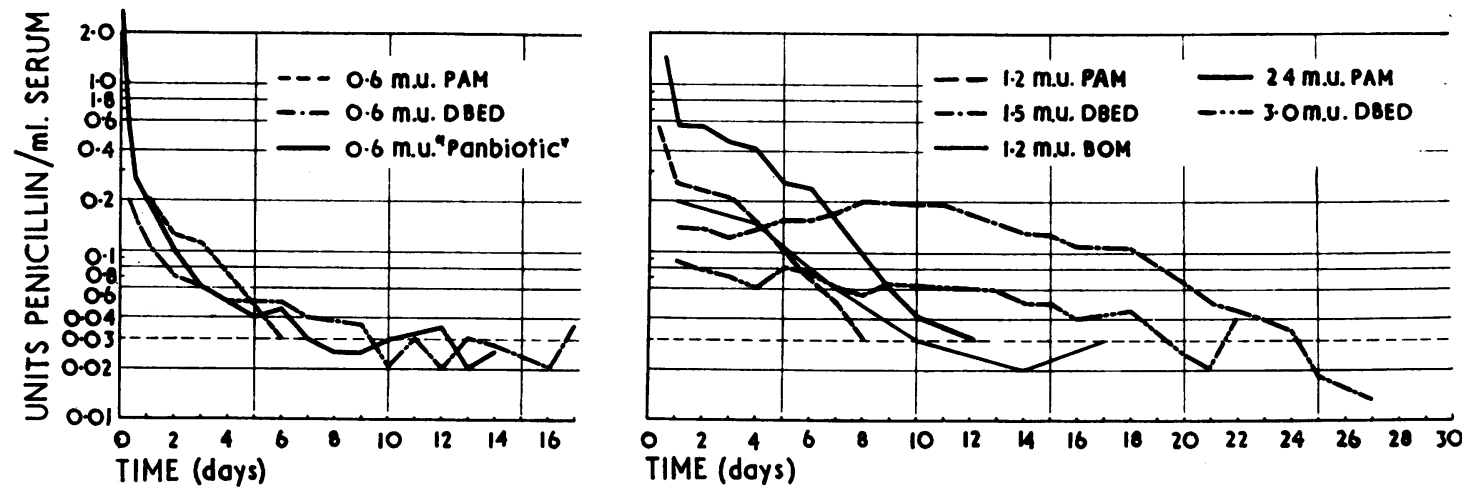

FIG. 3.-Duration of penicillinaemia following single injection of PAM, DBED, " Panbiotic ”, and BOM.

Sarcina lutea technique. Each curve is based on the findings in at least ten normal ambulant adults. Benzathine penicillin $G$ gives a penicillinaemia which has a duration approximately twice that obtainable with PAM (procaine penicillin $G$ in oil with aluminium monostearate). It will be particularly noted that, while 2.4 to 5.0 mega units PAM yield a treponemicidal blood-level above 0.03 units per ml. for 11 to 12 days, a very slightly higher dose of benzathine penicillin $G$ maintains this blood-level for more than 22 days. One exception will be observed, namely, the curve for 1.5 mega units DBED (benzathine penicillin $G$, aqueous), which appears to give longer penicillinaemia than 3.5 mega units DBED. This curve has been included to demonstrate the influence of weight and the difference in the resulting penicillinaemia in children as compared with that in adults.

With regard to "all-purpose penicillin", the main feature is the very high initial concentration of penicillin in the serum, concerning which Schamberg (1953) has stated :

I am wondering .... whether there is any theoretical basis for feeling that this high early concentration would bring about any better results in syphilis than does the lower blood level provided by Bicillin alone.

Some investigators have suggested that the very low blood concentrations resulting from benzathine penicillin may be insufficient to kill all treponemes in the infected host. This view is not borne out by the evidence furnished by laboratory workers, clinicians, and epidemiologists. First, penicillinsensitive micro-organisms retain and concentrate the antibiotic so that low levels in the environment may result in substantial concentrations, in the bacterial cell (Eagle, 1954); treponemes are one of the most penicillin-sensitive micro-organisms known. Secondly, the preventive value of benzathine penicillin against infection in the experimental animal as well as in human beings has been satisfactorily demonstrated. Thirdly, the clinical and serological results of treatment of actual clinical cases of treponematoses appear to be satisfactory. Shortterm observations on the therapeutic effectiveness of benzathine penicillin have been made in yaws (Grin, Guthe, Payanandha, D'Mello, and Swaroop, 1954), in pinta (Marquez, quoted by Rein and Mann, 1954), and in syphilis (Vilanova and Alvarado, 1954, and the WHO International Co-operative Clinical Group, of which the British Clinical Co-operative Group is a part). Long-term observations have also been made in the U.S.A. by Smith and his co-workers (1954b). Shafer and Smith (1954) compared the results of treatment schedules of 2.4 mega units benzathine penicillin with those of 4.8 mega units PAM in previously untreated secondary syphilis over a period of two years (Fig. 4). Their results show that a dose of 2.4 to 2.5 mega units benzathine penicillin compares favourably with

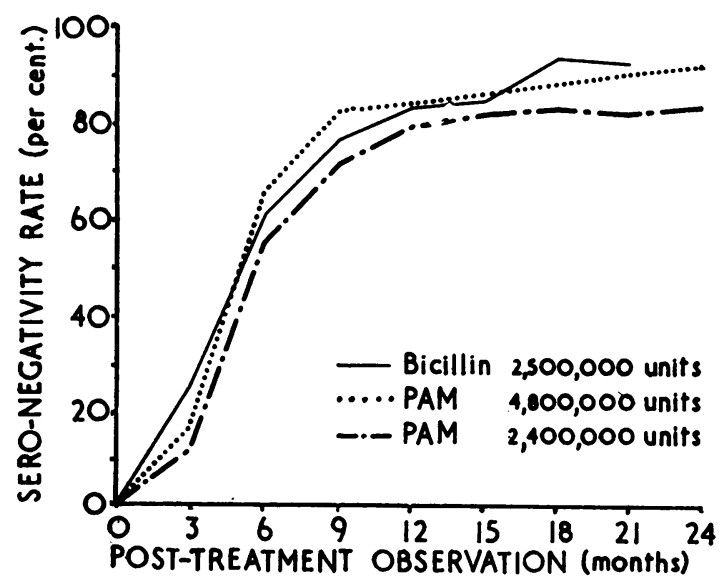

Fig. 4.-Comparison of results of bicillin and of PAM in previously untreated secondary syphilis : rate of reversal to sero-negativity. 
one of 4.8 mega units PAM. This is to be expected because of the duration of penicillinaemia resulting from benzathine penicillin, since it is not the dosage per se or the number of injections which determines the effectiveness of the penicillin, but rather the duration of the exposure of the treponemes to the antibiotic. This is determined by the physical, pharmacodynamic, and other characteristics of the penicillin preparation used. It is to be regretted that so often in the past the therapeutic effects of penicillin preparations have been expressed only in terms of units and dosages without sufficient regard to the time/exposure factor.

The various trials in treponematoses show that benzathine penicillin is a suitable preparation for individual and clinic practice. It has simplified the management of syphilis further by permitting single-session therapy to be given with a longeracting drug in a lesser volume and in an aqueous suspension. It is, one might say, the one penicillin preparation so far available which has "time on its side". In mass campaigns in rural underdeveloped areas the considerations regarding the practical use of benzathine penicillin are, at present, somewhat different. The administration of a drug which is not " ready-to-inject " by medical auxiliaries working under primitive conditions, is not practicable; moreover, the use of benzathine penicillin requires more supervision and introduces greater problems in handling and sterilization than the "ready-to-inject" PAM. Furthermore, although the presuspended aqueous preparations of benzathine penicillin now available on the international market are suitable for clinical practice, none has so far been demonstrated to be stable under tropical conditions for any length of time. It is not likely, therefore, that benzathine penicillin will replace PAM in mass campaigns against the endemic treponematoses until aqueous preparations have been shown capable of withstanding such conditions. Certain field studies are however under way, with both aqueous benzathine preparations and benzathine penicillin in oil with aluminium monostearate. The initial results are encouraging.

\section{EPIDEMIOLOGICAL INDICATIONS FOR TREATMENT}

In communicable-disease control the use of preventive measures on epidemiological indications is well established. In addition to treatment of actual cases, prevention may include the isolation of infected individuals to avoid the spread of infection to susceptible contacts, the adoption of shortterm measures, such as the administration of protective sera or chemotherapeutic or antibiotic drugs to contacts without sign of disease, or a combination of these and other possible approaches in an effort to safeguard the public health. Obviously, consideration must be given to the cost of the method selected, and the relative risks in terms of side-effects must be carefully weighed in relation to the expected seriousness of the acute, chronic, or morbid conditions resulting in the infected individual and population. The price to be paid for such protection in terms of serious complications, and sometimes fatalities, is well known with procedures such as vaccination against smallpox, yellow fever, tuberculosis (BCG), and rabies, or following the protective use of sera and gamma globulin.

The studies undertaken on the preventive use of drugs during the past few decades, particularly those with antimalarials, are well known, as are experiences with sulphonamide products in infections with staphylococci, meningococci, streptococci, gonococci, certain intestinal pathogens, and other micro-organisms. The preventive use of antibiotics in susceptible infections introduced no new principle, but the greater effectiveness, lower toxicity, and fewer complications and side-reactions associated with antibiotic products made possible an extension of the range of preventive medication. Thus, for several years penicillin and other antibiotics have been extensively used in prolonged or intensive courses in surgery, to prevent various infections, ranging from those following bowel resection or bone surgery to the management of surface wounds and burns. The introduction of repository procaine and benzathine penicillin with long-lasting bactericidal blood-levels has further added to the preventive effectiveness of antibiotics. These are also used in ear, nose, and throat infections, and in dentistry where benzathine penicillin is apparently beginning to replace other penicillin salts (Nathanson, Morin, and Mallet 1953).

Macchiavello, Omar, El Sayed, and Rahman (1954) demonstrated the effectiveness of mass penicillin (PAM) prophylaxis among cerebrospinal meningococcal meningitis contacts and carriers in the Sudan. Pollitzer (1954) has pointed out the impressive preventive effect of streptomycin when given to contacts in endemic plague areas. Lyons (1947) used aureomycin protectively in the mass control of trachoma and acute seasonal conjunctivitis in Egypt and Morocco. In the U.S.A. Seal and others (1953) showed the preventive effect in streptococcal respiratory infections of procaine penicillin and chlortetracycline used over a period of 6 to 8 weeks in a naval population. In the United Kingdom similar epidemiological mass-treatment schemes have been used in the prevention of scarlet fever 
and sore throat epidemics. In combating the recurrence of rheumatic fever, concern is not with a micro-organism already present in the throat of the individual in whom the disease is in the quiescent state, but with the prevention of Group A streptococcal infection. Monthly intramuscular injections of benzathine penicillin for 1 year were shown by Stollerman and Rusoff (1952) to be completely effective in preventing this infection in children. Karelitz, Chang, and Matthews (1954) showed that procaine penicillin and benzethacil were highly effective in the prevention of bacterial complications of measles. The observations of Stollerman and Rusoff have subsequently been confirmed by a number of other investigators Tidwell, 1954 ; Perry and Gillespie, 1954 ; Edström, 1954; Breese, 1953 ; Chamovitz and Catanzaro, 1953). In elderly patients with bronchial asthma and pulmonary emphysema, benzathine penicillin is of value in preventing respiratory infections due to haemolytic streptococci, pneumococci, and non-resistant staphylococci (Barach, 1953).

These are selected examples of current preventive uses of penicillin. There are many other fields in which this and other antibiotics are now being used, but where the indications are less clearly defined and where the immediate and long-range effectiveness cannot be readily evaluated. No doubt there is a certain amount of misuse of antibiotics in most countries to-day, both in curing and in preventing infections. Caution in their use should undoubtedly be exercised by the medical profession, and their application should be confined to specific clinical or preventive indications. Finland (1953) has stated that, in the evaluation of the preventive use of chemotherapeutic and antibiotic drugs, serious consideration must be given to :

(a) the price to be paid in side-effects ;

(b) the best method of accomplishing a set objective ;

(c) the types of preventive use to which antibiotics should be put.

The preventive use of penicillin may thus be classified under two heads :

(1) Short duration, for a specific purpose, such as individual prevention (e.g., in ophthalmia neonatorum), or mass prophylaxis (in meningococcus infection) ;

(2) Long or continuous use, e.g., aureomycin for endemic trachoma, or penicillin for rheumatic fever.

Preventive penicillin treatment may also serve such uses in the management of the treponematoses and WHO has therefore followed with considerable interest the growing practice and the accumulating experience in many countries.
Before discussing these aspects, however, it may be useful to record the following definitions :

(1) Prophylactic Treatment.-This concerns susceptible individuals who may become infected with treponemes; e.g., the prophylactic treatment of susceptible contacts in areas of endemic treponematoses ; prophylaxis before venereal exposure ; or indirect prophylaxis by the treatment of pregnant syphilitic women before the foetus is infected.

(2) Abortive Treatment.-This concerns individuals in the pre-clinical stage who are proved to be, or suspected of being, infected : e.g., contacts in the incubation period in areas of endemic treponematoses; individuals given treatment after venereal exposure; or treating the syphilitic pregnant woman after the fourth month to cure the disease already established in the foetus.

(3) Protective Treatment.-This is also being applied protectively in clinical mass campaigns, where it is given to individuals without overt signs of the infection who are really latent cases, but where no laboratory examinations are practicable, and where the aim is to prevent serological and clinical relapses of an already established infection.

While a classification of this kind may be highly desirable, it is not always possible to make such distinctions and the term "preventive" (or "epidemiological") treatment is now frequently used to cover all these eventualities.

\section{Preventive Treatment in Venereal Syphilis and Gonorrhoea}

In venereal syphilis (and gonorrhoea) preventive treatment has its scientific basis largely in the experimental work of Eagle (1949), and Magnuson and Eagle (1945), as confirmed by Levaditi, Penau, Vaisman, and Hagemann (1949) and others. The studies of Plotke, Eisenberg, Baker, and Laughlin (1949), Alexander and Schoch (1949), and Alexander, Schoch, and Mantooth (1949) in small series of early syphilis patients and their contacts are well known, as are the views of Leifer and Martin (1946), Durel (1954), and others on the epidemiological effectiveness and applicability of preventive treatment. Only passing reference will be made therefore to the work of these investigators as well as to the practical experience of Eagle, Gude, Beckman, Mast, Sapero, and Shindledecker (1948, 1949), Campbell, Dougherty, and Curtis (1949), Babione, Hedgecock, and Ray (1952), and similar unpublished experiences of British workers in the prevention of gonorrhoea or syphilis among naval personnel in ports. The evidence suggests that preventive dosages of penicillin in syphilis, or corresponding dosages given therapeutically in gonorrhoea, do not generally " mask" the syphilitic 
infection, but apparently prevent it altogether. Retardation of the appearance of lesions or the uncovering of the disease by a Herxheimer reaction may occur, but these are extremely rare. Recently these observations have been supported by careful investigations (Kolmer, 1954), which indicate that, in the prophylaxis and abortion of syphilitic infection, repository PAM is highly effective, and that benzathine penicillin is almost four times more effective than PAM.

This demonstrated effectiveness of preventive penicillin treatment does not mean that the use of this or other antibiotics on epidemiological indication is the accepted practice everywhere. There are different views on the subject, not only for venereal syphilis and gonorrhoea but also for the possible risks of syphilitic infection incurred by physicians, dentists, nurses, midwives, and medical technologists in the course of their professional duties. Some of these views have recently been published in this journal (King, 1954; Willcox, 1954). New problems have arisen, ranging from speculation on the ultimate consequences of possible misuse of antibiotics by the profession to the psychological impact which the preventive use of penicillin might have on the public. On the latter aspect two opposing views are encountered. One is that venereal diseases still strike terror in the hearts of many patients, and that fear and uncertainty about infection are often more catastrophic than infection itself ; while the other contends that the ease with which the public now believes that syphilis and gonorrhoea can be prevented and cured with antibiotics has largely removed the fear often associated with these infections in the past. There is a growing tendency for the public to regard these infections as they would any other communicable disease.

Among the problems posed by the use of penicillin on epidemiological indications is that of the financial responsibility of health insurance and social security organizations. Thus, in Germany, the question actually led to an international survey of opinion among venereologists on preventive treatment, with particular reference to married partners, to which McElligott (1953) contributed on the British side. Of the twelve participants nine favoured preventive penicillin treatment-some with certain reservations-while three preferred to treat patients after the development of clinical lesions. One participant favoured preventive treatment if gonorrhoea was expected, but not if syphilis was the hazard.

Other countries have gone further in this question than is perhaps generally recognized; for example, Mexico (Campos Salos, 1952, 1953) and the U.S.A. (personal communication, 1955). In the U.S.A., health directives now prescribe in detail the procedures to be followed. The following quotation is from the Venereal-Disease-Control Manual of Maryland State (1954) :

For some time now it has been customary to treat female contacts of gonorrhoea solely on epidemiological grounds. The application of this same principle to alleged sexual contacts of primary and secondary syphilis has been made in several States and in controlled experimental demonstrations. There is no doubt that this procedure materially reduces the number of cases of early syphilis developing in the contact group. Obviously the advantage lies in

(a) the avoidance of symptomatic infection among contacts without clinical evidence of infection who are in the incubation period of the disease at the time of their initial examination, and who would either delay reporting for medical care after the development of infectious lesions or would be completely lost from observation, and

(b) a considerable saving in the time required of personnel in the follow up of such contacts.

Alleged sexual contacts of primary and secondary syphilis should therefore be treated, following a physical examination and a serological test for syphilis at the time of their initial visit to the clinic. If they are found to have clinical syphilis at that visit they will of course receive the same schedule of treatment as would any other case with the same manifestations. If, on the other hand, they show no evidence of disease they should be given 1.2 million units benzathine penicillin G (or 2.4 mega units PAM) in a single injection...

Although statistical data indicate that the annual incidence of new cases of early syphilis in the U.S.A. as a whole is no higher than that recorded in the Scandinavian countries, penicillin treatment on epidemiological grounds has apparently been accepted as a new weapon in the control of venereal syphilis (and of gonorrhoea). The reason for this is perhaps that small epidemics of venereal syphilis still occur from time to time in the U.S.A. This is shown in Fig. 5 (overleaf), which depicts an outbreak of obvious clinical syphilis in Georgia in 1953 (Olansky and Price, 1955).

The relevant observation by the authorities on this remarkable epidemiological episode was as follows :

On this occasion an individual rejected by his draft board was diagnosed as having secondary syphilis. As a result of contact tracing and interviewing, approximately seventy cases of primary and secondary syphilis were detected. In addition, approximately 200 other patients were treated prophylactically because they had been exposed to syphilis, and enough man-power was not available to apply proper follow-up procedures to these people. 


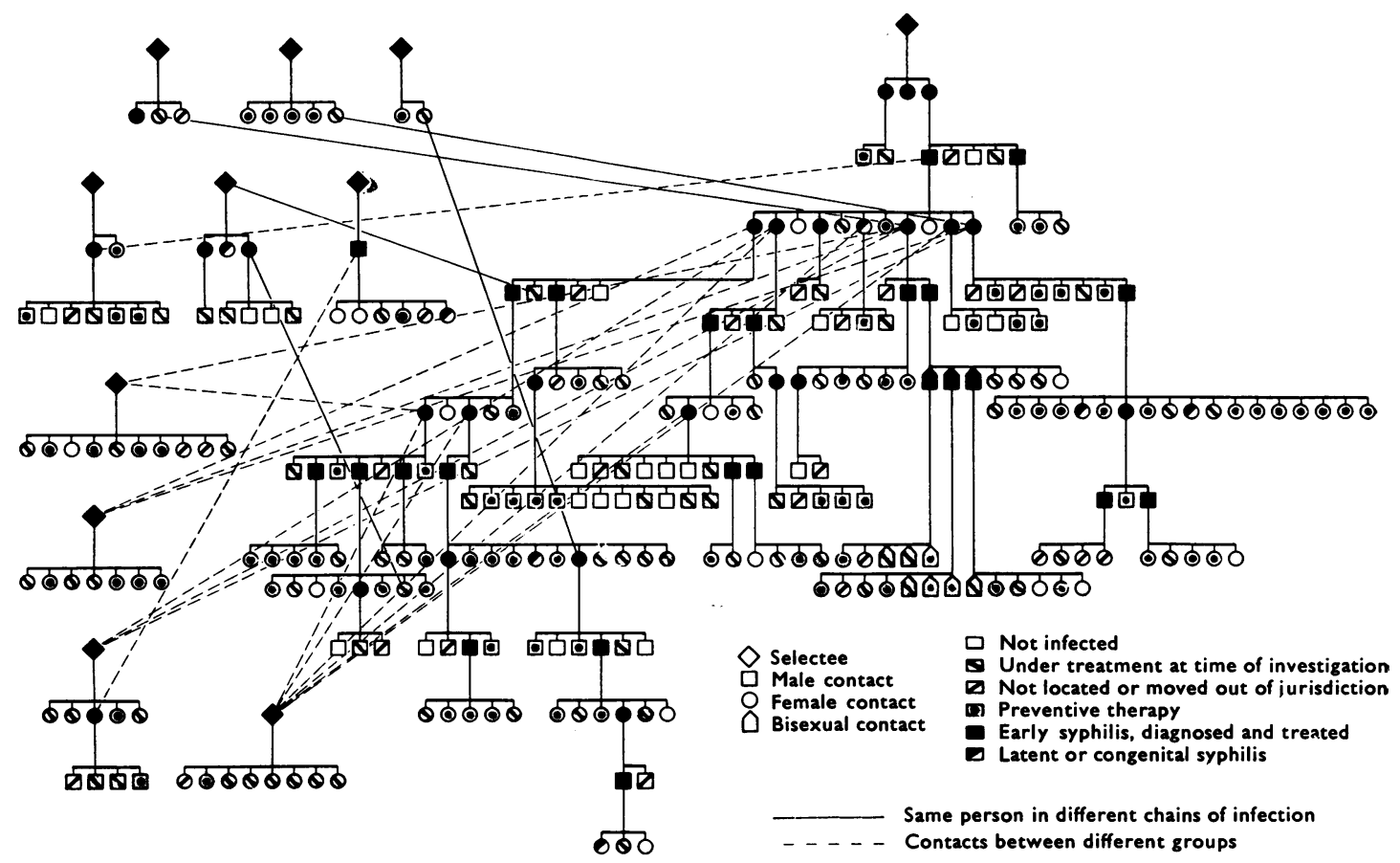

FIG. 5.-Schematic diagram of the epidemiology of a secondary syphilis case, Troup County, Ga, U.S.A. (August 17-October 1, 1953) (Olansky).

Contact investigation indexes : contact index, 4.98; epidemiological index, $2 \cdot 37$; brought to $R_{x}$ index, 0.96 ; lesion to lesion index, 0.88 .

From the references already made concerning the management of venereal diseases in the U.S.A. it is clear that, in that country, the preventive effect of repository penicillin is relied upon to such an extent that it becomes a supplementary arm in epidemiological work. At the same time emphasis is being placed on the post-treatment observation of contacts who have received preventive treatment. Such contacts should be followed monthly for the first 3 months, quarterly for the remainder of the first year, and annually thereafter.

All cases of gonorrhoea are given 0.6 mega unit benzathine penicillin, since this schedule allows adequate time for tracing and treating the regular sexual contacts of the patient, thereby preventing "ping-pong" infections. Moreover, it represents adequate treatment for the majority of persons who may be incubating syphilis. In the U.S.A. gonorrhoea patients so treated are advised to return 4 months later for a follow-up examination and a serological test for syphilis.

In venereal syphilis, Durel (1954) has advocated the use of benzathine penicillin in prostitutes, with appropriate maintenance doses given every 3 to 4 weeks. This procedure follows a pattern similar to that previously used in Mexico (Campos
Salos, 1952, 1953), Burma, and Hong Kong (reports to WHO), where PAM was given weekly. Recently we have had an opportunity of studying in some detail the effect of benzathine penicillin in two female population groups exposed to infection. The results are presented in Table II (opposite).

The two groups were living under identical conditions in a walled-off, " red-light" district of a city, in, let us say, Ruritania. The follow-up percentages by the end of 12 months' observation were 91 and 92 for the test group and the control group, respectively. The cumulative attack rate of early clinical syphilis was 13.6 per cent. in the control group and appeared to be 3.9 per cent. in the test group ; this percentage of 3.9 represented one case only-a woman who had missed her previous monthly injection with benzathine penicillin. Sero-positivity in the test group showed a declining tendency, although the difference by the end of the first 12 months was not statistically significant. However, the trend is suggestive of a "curative effect" in latent syphilis by a regime which by some investigators might be compared to the practice of "consolidation" treatment. 
TABLE II

INCIDENCE OF INFECTIOUS SYPHILIS IN EXPOSED FEMALE POPULATION

\begin{tabular}{|c|c|c|c|c|c|c|c|c|c|c|c|c|}
\hline \multirow{3}{*}{$\begin{array}{l}\text { Number of } \\
\text { Months } \\
\text { after } \\
\text { Beginning } \\
\text { of Trial }\end{array}$} & \multicolumn{6}{|c|}{ Test Group (Monthly “ Maintenance” Doses*) } & \multicolumn{6}{|c|}{ Control Group (Clinical Cases Treated) } \\
\hline & \multirow[b]{2}{*}{$\begin{array}{l}\text { Number } \\
\text { Examined }\end{array}$} & \multicolumn{2}{|c|}{ Sero-reactors } & \multicolumn{2}{|c|}{ Primary, Secondary } & Lesions $†$ & \multirow[b]{2}{*}{$\begin{array}{l}\text { Number } \\
\text { Examined }\end{array}$} & \multicolumn{2}{|c|}{ Sero-reactors } & \multicolumn{3}{|c|}{ Primary, Secondary Lesions $\dagger$} \\
\hline & & Number & Per cent. & Number & $\begin{array}{l}\text { Per cent. } \\
\text { of Total }\end{array}$ & $\begin{array}{l}\text { Cumu- } \\
\text { lative } \\
\text { per cent. }\end{array}$ & & Number & Per cent. & Number & $\begin{array}{l}\text { Per cent. } \\
\text { of Total }\end{array}$ & $\begin{array}{l}\text { Cumu- } \\
\text { lative } \\
\text { per cent. }\end{array}$ \\
\hline $\begin{array}{r}0 \\
1 \\
2 \\
3 \\
4 \\
5 \\
6 \\
7 \\
8 \\
9 \\
10 \\
11 \\
12\end{array}$ & $\begin{array}{l}32 \\
31 \\
29 \\
30 \\
28 \\
29 \\
29 \\
30 \\
29 \\
28 \\
27 \\
28 \\
29\end{array}$ & $\begin{array}{r}14 \\
13 \\
12 \\
12 \\
11 \\
11 \\
10 \\
11 \\
9 \\
8 \\
7 \\
8 \\
6\end{array}$ & $\begin{array}{l}43.7 \\
41.9 \\
41.4 \\
40.0 \\
39.3 \\
37.9 \\
34.5 \\
36.7 \\
31.0 \\
28.6 \\
25.9 \\
28.6 \\
20.7\end{array}$ & $\begin{array}{l}1 \\
0 \\
0 \\
0 \\
0 \\
0 \\
0 \\
0 \\
0 \\
0 \\
0 \\
1 \\
0\end{array}$ & $\begin{array}{l}-\overline{0.0} \\
0.0 \\
0.0 \\
0.0 \\
0.0 \\
0.0 \\
0.0 \\
0.0 \\
0.0 \\
0.0 \\
3.9 \\
0.0\end{array}$ & $\begin{array}{l}-\overline{0.0} \\
0.0 \\
0.0 \\
0.0 \\
0.0 \\
0.0 \\
0.0 \\
0.0 \\
0.0 \\
0.0 \\
3.9 \\
3.9\end{array}$ & $\begin{array}{l}54 \\
53 \\
51 \\
49 \\
51 \\
50 \\
49 \\
50 \\
49 \\
49 \\
50 \\
49 \\
50\end{array}$ & $\begin{array}{l}23 \\
22 \\
20 \\
19 \\
22 \\
21 \\
20 \\
21 \\
22 \\
21 \\
20 \\
22 \\
22\end{array}$ & $\begin{array}{l}42.5 \\
41 \cdot 5 \\
39.2 \\
38.8 \\
43 \cdot 1 \\
42.0 \\
40.8 \\
42.0 \\
44.9 \\
42.9 \\
40.0 \\
44.9 \\
44.0\end{array}$ & $\begin{array}{l}0 \\
2 \\
1 \\
0 \\
0 \\
1 \\
0 \\
0 \\
1 \\
0 \\
0 \\
2 \\
0\end{array}$ & $\begin{array}{l}-\overline{3 \cdot 8} \\
2.0 \\
0.0 \\
0.0 \\
2.0 \\
0.0 \\
0.0 \\
2 \cdot 0 \\
0.0 \\
0.0 \\
4 \cdot 1 \\
0.0\end{array}$ & $\begin{array}{r}-1.8 \\
5.8 \\
5.8 \\
5.8 \\
7.8 \\
7.8 \\
7.8 \\
9.8 \\
9.8 \\
9.8 \\
13.9 \\
13.9\end{array}$ \\
\hline
\end{tabular}

* 2.4 mega units benzathine penicillin $G$ given preventively at monthly medical examinations.

+ Clinical cases were treated with 4.8 mega units PAM in one session.

Preventive Treatment in Non-venereal, Endemic non-venereal treponematosis, found predominantly Treponematoses in children, was a communicable household

Penicillin treatment on epidemiological grounds disease (Fig. 6). for the mass management of the non-venereal, endemic treponematoses has also received considerable attention in recent years. The question has been asked : "Is preventive treatment likely to be effective in diminishing the incidence of these infections?" Recent experience may throw some light on this. Grin (1953) convincingly demonstrated the effectiveness of preventive treatment in endemic syphilis areas in Bosnia, and he observed that this

- Secondary syphilis

$\oplus$ Congenital syphilis

(1) Latent syphilis

O Clinically and serologically negative

(1) Serological improvement

Treated $(3,600,000$ units PAM; abortive treatment: 1,200,000 units)

FIG. 6.-." Ping-pong" infection and re-infection in two infected families and epidemiological effect of abortive treatment (M. N. O. Sapna).
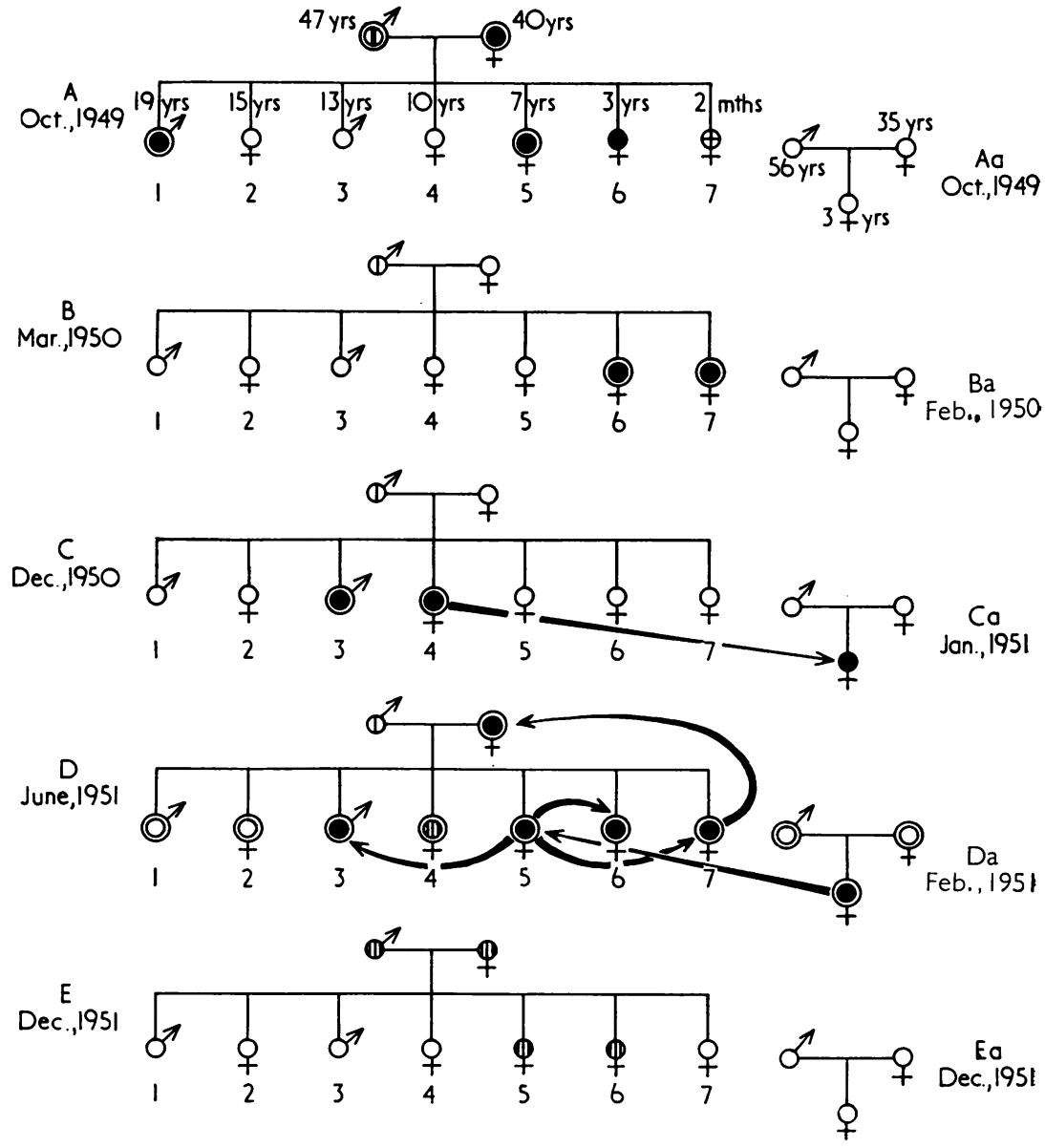
TABLE III

EPIDEMIOLOGICAL EFFECT OF CONTACT TREATMENT IN TREPONEMATOSES MASS CAMPAIGNS

\begin{tabular}{|c|c|c|c|c|c|c|c|c|c|c|c|c|c|c|c|c|c|c|}
\hline \multirow{4}{*}{$\begin{array}{l}\text { Treatment } \\
\text { Policy }\end{array}$} & \multirow{4}{*}{$\begin{array}{c}\text { Popula- } \\
\text { tion } \\
\text { Exam- } \\
\text { ined } \\
\text { (Mean) }\end{array}$} & \multirow{4}{*}{$\begin{array}{c}\text { Per- } \\
\text { centage } \\
\text { Exam- } \\
\text { ined of } \\
\text { Total } \\
\text { Popula- } \\
\text { tion }\end{array}$} & \multicolumn{8}{|c|}{ Infectious Lesions } & \multicolumn{8}{|c|}{ Sero-reactors } \\
\hline & & & \multicolumn{4}{|c|}{ Number of Cases } & \multicolumn{4}{|c|}{ Per 1,000 Population } & \multicolumn{4}{|c|}{ Number of Reactors } & \multicolumn{4}{|c|}{ Per 1,000 Population } \\
\hline & & & \multicolumn{4}{|c|}{ Survey } & \multicolumn{4}{|c|}{ Survey } & \multicolumn{4}{|c|}{ Survey* } & \multicolumn{4}{|c|}{ Survey } \\
\hline & & & $\mathbf{I}$ & II & III & IV & I & II & III & IV & I & II & III & IV & I & II & III & IV \\
\hline Clinical cases only .. & 17,526 & $95 \cdot 9$ & 1,329 & 315 & 82 & 53 & $75 \cdot 8$ & $18 \cdot 0$ & $4 \cdot 7$ & $3 \cdot 0$ & $\dagger$ & + & + & 1,522 & $\dagger$ & + & $\dagger$ & $86 \cdot 8$ \\
\hline $\begin{array}{rr}\text { Clinical and } & \text { serolo- } \\
\text { gical cases } & .\end{array}$ & 17,838 & $96 \cdot 4$ & 959 & 42 & 34 & 12 & 53.8 & $2 \cdot 4$ & 1.9 & $0 \cdot 7$ & 4,823 & 2,504 & 1,065 & 321 & $270 \cdot 4$ & $140 \cdot 4$ & $59 \cdot 7$ & $18 \cdot 0$ \\
\hline $\begin{array}{l}\text { Clinical and serological } \\
\text { cases and contacts } \ddagger\end{array}$ & 16,990 & $97 \cdot 5$ & 923 & 8 & $\mathbf{0}$ & 2 & $54 \cdot 3$ & $0 \cdot 5$ & 0.0 & $0 \cdot 1$ & 4,715 & 1,671 & 611 & 153 & $277 \cdot 5$ & $98 \cdot 4$ & $36 \cdot 0$ & $9 \cdot 0$ \\
\hline
\end{tabular}

* Survey intervals 6 to 10 mths.

$\uparrow$ Not examined.

¥ All children under 18 yrs, plus members of household with one or more infectious cases.

In two households the treatment of clinical and/or serological cases alone did not prevent perpetuation of the disease through cross-infections or reinfections. Only simultaneous preventive penicillin treatment of household members without overt signs of the disease, but exposed to the risk of infection, eliminated it. These observations were made over a period of $2 \frac{1}{2}$ years during which time all household members were clinically and serologically examined and re-examined at five different surveys. Similar observations have been made in other programmes.

The mass effect of preventive penicillin treatment in treponematoses campaigns has also been studied in three endemic areas with approximately the same population, in order to compare different treatment policies (Table III). The basic data and percentage reduction in infections and seropositivity are also shown graphically (Fig. 7).

Preventive treatment procedures have been used in many treponematoses programmes, e.g., the Gold Coast, India, Liberia, Morocco, Nigeria, the Philippines, Thailand, and elsewhere. From the experience gained in these campaigns it has become clear that preventive treatment at the initial survey will not only suppress most rapidly and economically the foci of infection in the community, but will also

(a) reduce the number of resurveys required to eliminate the infection in rural villages ;

(b) prolong the interval between resurveys ;

(c) reduce the overall cost of treponematoses programmes ;

(d) permit of a more rapid consolidation and the development of a general health programme where treponematoses control has been used as a spearhead.

Data on the use of benzathine penicillin G on epidemiological indications in the endemic treponematoses are still limited owing to the present unsuitability of preparations for field use. It is nevertheless clear that the longer-lasting treponemi- cidal blood- and tissue-levels given by this drug will increase the prophylactic value of penicillin in susceptible contacts during mass campaigns ; when stable presuspended benzathine penicillin preparations become available there will be more time in the mass programme to suppress active foci from which the infection might again spread in the community. The application of such preparations in the incubation period will increase the likelihood of aborting completely the treponemal infection, while at the same time providing an extended period of protection against re-infection in exposed

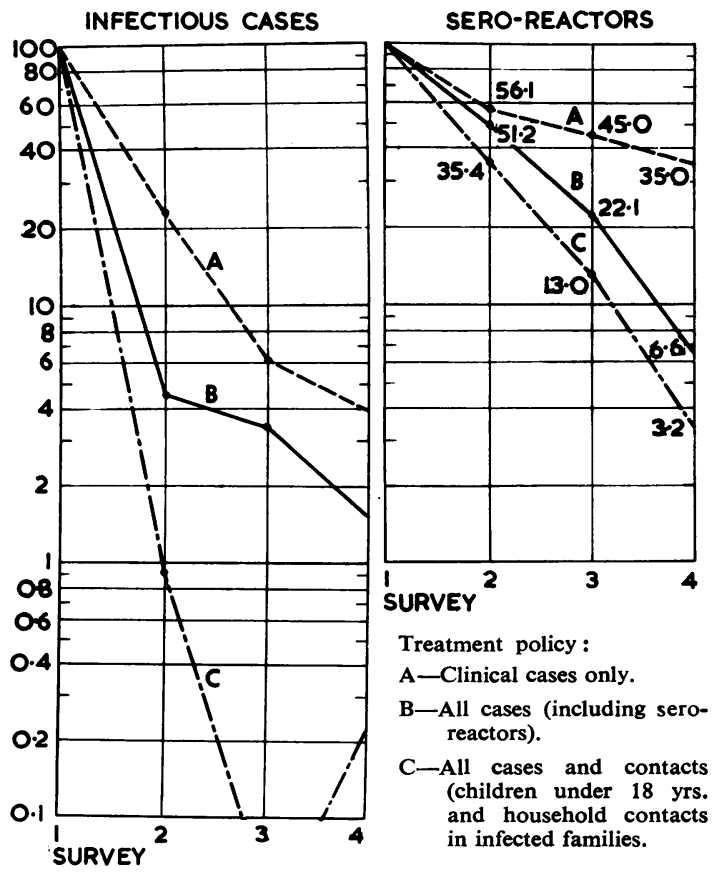

FIG. 7.-Infectious cases and sero-reactors of four surveys (undertaken at intervals of 6 to $\mathbf{1 0}$ months) according to three different treatment policies. 
individuals. In undiagnosed latency in clinical mass campaigns the prolonged penicillinaemia will tend to provide greater protection against relapses.

Although the experimental evidence in animals and man suggests the effectiveness of proportionately smaller dosages of penicillin for preventive purposes-and this, for reasons of economy, is the principle currently followed in mass campaigns against the non-venereal treponematoses-the tendency in venereal syphilis appears to be towards the use of relatively large dosages in preventive treatment. This trend has developed simultaneously with the tendency:

(a) to increase the penicillin dosage in gonorrhoea to ensure that adequate therapy is provided for a syphilitic infection in the incubation period at the time of treatment ;

(b) to increase the penicillin effect through the use of appropriate dosages of longer-acting preparations such as benzathine penicillin $\mathbf{G}$.

In the foregoing discussion, reference has, in general, been made to the intramuscular use of penicillin, except for a brief reference to the use of oral tablets among naval personnel in ports. Several years ago the WHO Expert Committee on Venereal Infections and Treponematoses warned against the uncertainties and dangers of penicillin tablet medication in gonorrhoea and the treponematoses, and this view now appears to be generally accepted.

\section{Side-effects of Penicillin}

Turning now to an appraisal of the side-effects resulting from the use of penicillin in the management of the treponematoses, the Jarisch-Herxheimer reaction in infected individuals and the possible development of penicillin resistance in the treponeme are only mentioned in passing, since the lysis phenomenon is a fairly constant feature with any kind of effective antisyphilitic drug and since resistance has not so far proved of practical importance.

Of the greatest importance, however, is the risk of sensitization of the host, of which many drugs are capable. Untoward reactions might therefore be expected with antibiotics as well. Since reactions may be expected to become more frequent as an increasing segment of the population has an opportunity to become sensitized from repeated exposure, it is noteworthy that the oldest and most widely used antibiotic - penicillin - has been scrutinized in this light only during the past few years. But it is now well established that penicillin may cause serum-sickness-like reactions (delayed urticaria, dermatographia, angioneurotic oedema, etc., or fixed skin eruptions (contact dermatitis) exfoliative dermatitis, etc.). These reactions are usually controlled with antihistaminic drugs. On the other hand there are the more important acute, anaphylactic reactions, profound, dangerous, and sometimes immediately fatal, which may follow oral and parenteral administration, or as a result of inhalation or instillation.

Sensitization reactions presuppose the presence of penicillin antibodies in the fluids and tissues of the host. Although the existence of such antibodies has so far not been demonstrated, studies are proceeding at the International Treponematosis Laboratory Center, where the application of new techniques developed by Dr. Ovary of Rome may make it possible to detect very small amounts of antibody. This approach may provide a new tool for the study of the entire problem of penicillin sensitization and the nature of antibodies formed in response to antibiotics.

The first fatal penicillin reaction was reported by Waldbott (1949) and others have since been published in England, France, and the U.S.A. (Stroud, 1952 ; Mayer and others, 1953 ; Siegal, Steinhardt, and Gerber, 1953). In an incomplete survey in the U.S.A. in 1953, the Food and Drug Administration found nineteen fatalities among 59 reactors to penicillin over a period of 2 years in 95 major American hospitals, representing 51,000 hospital beds (Welch, Lewis, Kerlan, and Putnam, 1953). One fatal case was from oral benzathine penicillin G. Since then many studies have been carried out by a number of investigators (O'Brien and Smith, 1952 ; Nathanson and others, 1953 ; Lepper and others, 1952 ; Feinberg, Feinberg, and Moran; 1953 ; Smith and others, 1954b). Reports of more than 150 anaphylactoid reactions from all types of penicillin have now been published. In view of this, the frequency and severity of reactions to be expected in the management of the treponematoses have become of major interest to the treponematologist and the venereologist.

Kitchen, Rein, Thomas, and Spoor (1951) reported that of 2,106 hospitalized syphilis patients, 4 per cent. were reactors to penicillin. No severe reactions or fatalities were observed among them. Jimenez Quiros (1952) reported 4.5 per cent. reactions in syphilitic patients in Costa Rica, and Welch and others (1953) that many of the severe reactions followed procaine penicillin, but made no mention of any fatalities among the syphilitic patients. Apart from two cases of anaphylactoid reactions reported by Smith and others (1954b), surprisingly few severe anaphylactoid reactions have been reported in gonorrhoea or 
treponematoses patients in spite of the fact that, in 10 years, millions of people have been given penicillin.

O'Brien and Smith (1952) reported transient dermatitis medicamentosa in 0.3 per cent. of 1,377 patients treated for syphilis with benzathine penicillin G, and Shafer and Smith (1954) found a similar percentage of reactors. However, perhaps the most complete analysis of penicillin reactions is that reported in an unpublished study presented at a recent Symposium on Antibiotics in Washington, D.C. In this material reactions were classified as urticarial and serum-sickness-like reactions, and as anaphylactoid and "other" reactions. Between 1946 and 1950 in 185,577 patients at 36 V.D. centres participating in the United States Public Health Service V.D. programme there were three penicillin reactions per 1,000 patients with a fatality rate of $1: 100,000$ (Smith and others, 1954a). This contrasts sharply with the mortality of $1: 200$ with arsenicals given by intravenous drip and $1: 9,000$ resulting from neoarsphenamine therapy. In 1954 another survey was undertaken in 24 "preventive and control centres" in fourteen States in the U.S.A., and side-effects were studied in 16,345 patients treated with penicillin during a 3 months' period. The outcome of this investigation is presented in Table IV.

The following points are of interest :

(1) The total reactors averaged 6.67 per 1,000 and among them urticaria was the most frequent reaction, namely, $5 \cdot 5$ per 1,000 . Four anaphylactoid reactions occurred : $1: 1,000$, with no deaths.
(2) The frequency of reactors increased with the duration of the planned schedule and was lowest ( 2 to 3 per 1,000 ) in therapy schedules given in single sessions, and highest $(23$ to 60 per 1,000$)$ in therapy schedules lasting 2 weeks or more. The frequency of reactors to PAM and to benzathine penicillin on a "one session" basis were almost identical ( 2 to 3 per 1,000).

(3) The frequency of reactors also increased with increasing age-and therefore presumably with increasing penicillin experience-from an average of 3 per 1,000 in the age group 10 to 19 years to 18 per 1,000 in the age group 40 to 49 years. Additional effect was observed with increased duration of treatment schedules in the parallel age groups, with nineteen and 81 reactors per 1,000 , respectively.

(4) Among persons who had no reaction to previous penicillin only $4 \cdot 7$ per 1,000 showed side-effects from subsequent penicillin, while 9.5 per 1,000 treated with penicillin for the first time reacted to it. However, 101 per 1,000 of those who had reacted to previous penicillin also reacted to subsequent penicillin therapy.

(5) The highest incidence of reactions was found in the group treated for syphilis, including those given single-session therapy, where the incidence was 9.9 per 1,000 , compared with $2 \cdot 4$ and $2 \cdot 1$ per 1,000 among those receiving gonorrhoea and epidemiological treatment, respectively. The dosage in syphilotherapy was eight times that of gonorrhoea and contact treatment. This might account for the greater incidence of reactions, although it cannot be ignored that this group may include some Herxheimer reactions, which are recognized as being extremely difficult to differentiate from sensitization reactions.

The small chance that sensitizing reactions will occur in children and young people, or in populations with no previous penicillin experience,

TABLE IV

INCIDENCE OF REACTIONS IN 16,345 PERSONS TREATED WITH PENICILLIN

U.S. Public Health Service-April 15 to August 15, 1954

\begin{tabular}{|c|c|c|c|c|c|c|c|c|c|c|c|c|c|c|c|c|c|}
\hline \multirow{3}{*}{\multicolumn{3}{|c|}{$\begin{array}{l}\text { Treatment } \\
\text { Schedules }\end{array}$}} & \multicolumn{3}{|c|}{ Total } & \multicolumn{3}{|c|}{ Single-session } & \multicolumn{3}{|c|}{ 2-7 Days } & \multicolumn{3}{|c|}{ 8-14 Days } & \multicolumn{3}{|c|}{ Over 2 Weeks } \\
\hline & & & \multirow{2}{*}{$\begin{array}{l}\text { Total } \\
\text { Cases }\end{array}$} & \multicolumn{2}{|c|}{ Reactors } & \multirow{2}{*}{$\begin{array}{l}\text { Total } \\
\text { Cases }\end{array}$} & \multicolumn{2}{|c|}{ Reactors } & \multirow{2}{*}{$\begin{array}{l}\text { Total } \\
\text { Cases }\end{array}$} & \multicolumn{2}{|c|}{ Reactors } & \multirow{2}{*}{$\begin{array}{l}\text { Total } \\
\text { Cases }\end{array}$} & \multicolumn{2}{|c|}{ Reactors } & \multirow{2}{*}{$\begin{array}{l}\text { Total } \\
\text { Cases }\end{array}$} & \multicolumn{2}{|c|}{ Reactors } \\
\hline & & & & No. & Rate* & & No. & Rate* & & No. & Rate* & & No. & Rate* & & No. & Rate* \\
\hline $\begin{array}{l}\text { Epidemiologica } \\
\text { ment . . } \\
\text { Gonorrhoea } \\
\text { Syphilis .. }\end{array}$ & 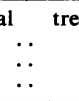 & $\begin{array}{l}\text { eat- } \\
\cdots \\
\cdots \\
\cdots\end{array}$ & $\begin{array}{l}2,903 \\
9,840 \\
3,337\end{array}$ & $\begin{array}{r}7 \\
27 \\
75\end{array}$ & $\begin{array}{r}2 \cdot 41 \\
2 \cdot 74 \\
22 \cdot 48\end{array}$ & $\begin{array}{l}2,889 \\
9,691 \\
1,888\end{array}$ & $\begin{array}{r}6 \\
25 \\
13\end{array}$ & $\begin{array}{l}2 \cdot 08 \\
2 \cdot 58 \\
6 \cdot 89\end{array}$ & $\begin{array}{r}13 \\
144 \\
350\end{array}$ & $\begin{array}{r}1 \\
2 \\
11\end{array}$ & $\begin{array}{l}76.92 \\
13.89 \\
31.43\end{array}$ & $\begin{array}{r}1 \\
5 \\
637\end{array}$ & $\frac{-}{25}$ & $\begin{array}{r}0.00 \\
0.00 \\
39 \cdot 25\end{array}$ & $\overline{4}$ & $\bar{z}$ & $\overline{56 \cdot 28}$ \\
\hline $\begin{array}{l}\text { PAM } \\
\text { Benzathine pe }\end{array}$ & nicillin & $\ddot{G}$ & $\begin{array}{r}12,179 \\
3,944\end{array}$ & $\begin{array}{l}97 \\
10\end{array}$ & $\begin{array}{l}7.96 \\
2 \cdot 54\end{array}$ & $\begin{array}{r}10,529 \\
3,856\end{array}$ & $\begin{array}{r}35 \\
9\end{array}$ & $\begin{array}{l}3 \cdot 32 \\
2 \cdot 33\end{array}$ & $\begin{array}{r}669 \\
23\end{array}$ & 14 & $\begin{array}{r}20.93 \\
0.00\end{array}$ & $\begin{array}{r}587 \\
23\end{array}$ & 24 & $\begin{array}{r}40 \cdot 89 \\
0 \cdot 00\end{array}$ & $\begin{array}{r}394 \\
42\end{array}$ & $\begin{array}{r}24 \\
1\end{array}$ & $\begin{array}{l}60.91 \\
23.81\end{array}$ \\
\hline $\begin{array}{c}\text { Age }(y r s): \\
10-19 \ldots \\
20-29 \ldots \\
30-39 \ldots \\
40-49 \ldots \\
50 \text { and over }\end{array}$ & $\begin{array}{l}\cdots \\
\cdots \\
\cdots \\
\cdots\end{array}$ & $\begin{array}{l}\cdots \\
\cdots \\
\cdots \\
\cdots\end{array}$ & $\begin{array}{r}3,484 \\
7,747 \\
2,906 \\
1,105 \\
970\end{array}$ & $\begin{array}{l}11 \\
34 \\
32 \\
20 \\
11\end{array}$ & $\begin{array}{r}3 \cdot 16 \\
4 \cdot 39 \\
11 \cdot 01 \\
18 \cdot 10 \\
11 \cdot 34\end{array}$ & $\begin{array}{r}3,253 \\
7,151 \\
2,479 \\
861 \\
699\end{array}$ & $\begin{array}{r}8 \\
12 \\
16 \\
6 \\
2\end{array}$ & $\begin{array}{l}2.46 \\
1.68 \\
6.45 \\
6.97 \\
2.86\end{array}$ & $\begin{array}{r}128 \\
276 \\
162 \\
74 \\
49\end{array}$ & $\begin{array}{l}1 \\
5 \\
3 \\
4 \\
1\end{array}$ & $\begin{array}{r}7 \cdot 81 \\
18 \cdot 12 \\
18 \cdot 52 \\
54 \cdot 05 \\
20 \cdot 41\end{array}$ & $\begin{array}{r}52 \\
204 \\
174 \\
96 \\
99\end{array}$ & $\begin{array}{r}1 \\
10 \\
6 \\
4 \\
3\end{array}$ & $\begin{array}{l}19 \cdot 23 \\
49 \cdot 02 \\
34 \cdot 48 \\
41 \cdot 67 \\
30 \cdot 30\end{array}$ & $\begin{array}{r}51 \\
116 \\
91 \\
74 \\
123\end{array}$ & $\begin{array}{l}1 \\
7 \\
7 \\
6 \\
5\end{array}$ & $\begin{array}{l}19 \cdot 61 \\
60 \cdot 34 \\
76.92 \\
81 \cdot 08 \\
40.65\end{array}$ \\
\hline $\begin{array}{l}\text { Previous penici } \\
\text { Reacted } \\
\text { Did not reac }\end{array}$ & $\begin{array}{l}\text { llin : } \\
\ldots \\
\text { t. }\end{array}$ & $\ddot{x}$ & $\begin{array}{r}109 \\
11,497\end{array}$ & $\begin{array}{l}11 \\
54\end{array}$ & $\begin{array}{r}100 \cdot 92 \\
4 \cdot 70\end{array}$ & $\begin{array}{r}90 \\
10,419\end{array}$ & $\begin{array}{r}7 \\
23\end{array}$ & $\begin{array}{r}77 \cdot 78 \\
2 \cdot 21\end{array}$ & $\begin{array}{r}10 \\
459\end{array}$ & $\overline{6}$ & $\begin{array}{r}0.00 \\
13.07\end{array}$ & $\begin{array}{r}6 \\
370\end{array}$ & $\begin{array}{r}3 \\
13\end{array}$ & $\begin{array}{r}500 \cdot 00 \\
35 \cdot 14\end{array}$ & $\begin{array}{r}3 \\
249\end{array}$ & $\begin{array}{r}1 \\
12\end{array}$ & $\begin{array}{r}333 \cdot 33 \\
48 \cdot 19\end{array}$ \\
\hline No previous pe & nicillin & .. & 3,353 & 32 & $9 \cdot 54$ & 2,770 & 7 & $2 \cdot 53$ & 182 & 6 & $32 \cdot 97$ & 237 & 7 & $29 \cdot 54$ & 164 & 12 & $73 \cdot 17$ \\
\hline
\end{tabular}

* Per 1,000 
confirms the observations made in mass treponematoses campaigns in underdeveloped areas (Haiti, Indonesia, Thailand, etc.) where a surprisingly small number of reactors has been observed. Parenteral penicillin is more likely to cause anaphylactoid reactions than oral penicillin, although reactions after the latter have also been reported. Persons with hay fever, asthma, or other allergies, or previous sensitivity to penicillin, are more likely to be anaphylactoid reactors. Anaphylactoid fatalities are preventable, and care should be taken to avoid accidental intravenous administration of penicillin. Calcium gluconate and resuscitation drugs should be ready for immediate use; the preliminary use of skin testing has been stated to be helpful in many instances and procaine amide may be effective in preventing penicillin reactions in known reactors (Jennings and Olansky, 1954).

It is not likely that the use of one penicillin salt will prevent sensitization reactions after the use of other penicillin salts, at least not for those at present in use, including benzathine penicillin.

Serious side-effects are not more prevalent with benzathine penicillin than with PAM in singlesession treatment schedules in the treponematoses. However, subjective complaints of local discomfort at the site of the injection are sometimes made after benzathine penicillin, but such complaints were not considered an objective criterion of "side-reactions" in the study material from the U.S.A. discussed in Table IV. That the procainefree benzathine penicillin may actually give rise to local pain more frequently than PAM is suggested by observations in Thailand (Grin, 1953), Morocco, Norway, and Britain (communications to WHO), although there may be doubts whether this can be considered a contraindication to the use of this preparation if its advantages are otherwise convincing.

On the whole, it may be said that the sensitizing potential of penicillin is remarkably low, and while the incidence of penicillin reactions has probably increased in some countries where the drug has been available for some time and has been widely used, reactions remain relatively infrequent considering the enormous quantity of penicillin consumed annually (estimated world production in 1954, 500 tons). Considerable reservation should be made on the general validity of published observations of the stated frequency of penicillin reactions in small, highly selected population samples, such as groups of hospital patients, etc., for material of this kind tends to over-emphasize the true incidence. In the long run the use of benzathine penicillin represents an advantage over
PAM. The use of single-session treatment schedules with benzathine penicillin and the lower dosages which can be effectively administered will tend to limit the degree of sensitization and the number of penicillin reactors. A practical consequence of this has been that in the U.S.A. the manufacture of PAM is now being discontinued in favour of benzathine penicillin.

\section{SUMMARY}

No small proportion of the world's penicillin production is used in the management of the treponematoses. The long-acting characteristics of procaine penicillin $G$ in oil with 2 per cent. aluminium monostearate-PAM-have, during the past few years, made it the penicillin preparation of choice, since the major factor in the effectiveness of penicillin is the time for which it maintains a treponemicidal level in the blood. The recent introduction of benzathine penicillin $\mathrm{G}$-which, when given intramuscularly, is absorbed and eliminated about twice as slowly as PAM-therefore represents a considerable advance in the further simplification of the management of treponemal infections.

Clinical trials have shown that the same curative effect can be obtained in early treponemal infections with a single injection procedure using a dosage of benzathine penicillin half that of PAM.

Preventive treatment on epidemiological indications is an established principle in the effective management of the non-venereal, endemic treponematoses. In some countries such procedures have also been introduced in the management of venereal syphilis (and gonorrhoea). The superior preventive effect of benzathine penicillin (as compared with PAM) has been demonstrated in individuals exposed to contagion and in individuals incubating the treponematoses.

The sensitizing potential of penicillin is low, but previous experience with the antibiotic, repeated application in prolonged treatment schedules, and possibly the use of large dosages, tends to increase the incidence of reactions. The price to be paid in side-reactions from penicillin is small in relation to its curative and preventive value, particularly when compared to the toxic reactions and mortality resulting from arsenotherapy. The introduction of benzathine penicillin in the management of the treponematoses will further limit the incidence of sensitization reactions, since lower dosages make one-session treatment schedules a practical proposition.

The data available on the place of benzathine penicillin in the management of the treponematoses 
are still incomplete and more time must elapse before a fuller evaluation of its advantages and disadvantages can be made. However, in some countries, benzathine penicillin $\mathrm{G}$ is already replacing PAM in clinical practice in the management of syphilis (and gonorrhoea). It is suggested that when more stable presuspended preparations become available benzathine penicillin might become the preparation of choice in the control of the non-venereal, endemic treponematoses.

\section{REFERENCES}

Alexander, L. J., and Schoch, A. G. (1949). Arch. Derm. Syph. (Chicago), 59, 1.

,-- and Mantooth, W. B. (1949). Amer. J. Syph., 33, 429.

Babione, R. W., Hedgecock, L. E., and Ray, J. P. (1952). U.S. armed Forces med. J., 3, 973.

Barach, A. L. (1953). Geriatrics, 8, 423.

Breese, B. B. (1953). J. Amer. med. Ass., 152, 10.

Buckwalter, F. H., and Dickison, H. L. (1948). J. Amer. pharm. Ass. (Sci. ed.), 37, 472.

Campbell, V. W. H., Dougherty, W. J., and Curtis, C. E. (1949). J. clin. Invest., 28, 1040.

Campos Salos, A. (1952). Bol. epidem. (Méx.), 16, 62.

-1953). Arch. mex. Venereol. Derm., 12, 63.

Chamovitz, R., and Catanzaro, F. J. (1953). In "Antibiotics Annual, 1953-1954" (Proceedings of the Symposium on Antibiotics, October 28, 29, and 30, 1953, Washington, D.C.), p. 113. Medical Encyclopedia Inc., New York.

Coriell, L. L., McAllister, R. M., Preston III, E., and Hunt, A. D. (1953). Antibiot. and Chemother., 3, 357.

Durel, P. (1954). Proph. sanit. morale, 26, 139.

Eagle, H. (1949). J. exp. Med., 90, 595.

(1954). Ibid., 99, 207.

- Fleischman, R., and Musselman, A. D. (1954). Amer. J. Med., 9, 280.

-, Gude, A. V., Beckmann, G. E., Mast, G., Sapero, J. J., and Shindledecker, J. B. (1948). Publ. Hlth Rep. (Wash.), 63, 1411

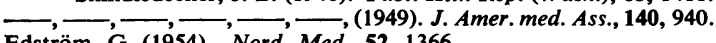

Edström, G. (1954). Nord. Med., 52, 1366.

Elias, W., Price, A. H., and Merrion, H. J. (1951). Antibiot. and Chemother., 1, 491.

Feinberg, S. M., Feinberg, A. R., and Moran, C. F. (1953). J. Amer. med. Ass., 152, 114.

Finberg, L., Leventer, I., and Tramer, A. (1953). Antibiot. and Chemother., 3, 353.

Finland, M. (1953). In "Antibiotics Annual, 1953-1954"'(Proceedings of the Symposium on Antibiotics, October 28, 29, and 30, 1953, Washington, D. C.), p. 10. Medical Encyclopedia Inc., New York.

Fletcher, A. P., and Knappett, C. R. (1953). Brit. med. J., 1, 188. Granatek, A. P., Gottstein, W. J., and Cheney, L. C. (1954). Antibiot. and Chemother., 4, 551.

Grin, E. I. (1953) "Epidemiology and Control of Endemic Syphilis : Report on a Mass-treatment Campaign in Bosnia." Monograph Series, No. 11. W.H.O., Geneva.

—, Guthe, T., Payanandha, L., D'Mello, J. M. F., and Swaroop, A. S. (1954). Amer. J. Syph., 38, 397.

Hill, K. R. Quoted by Rein and Mann (1954).

Idsoe, O. (1954). Personal communication.

Jennings, P. B., and Olansky, S. (1954). Ann. intern. Med., 40, 711.

Jiménez Quirós, (1952). Rev. med. C. Rica, 19, 103.

Karelitz, S., Chang, C. C., and Matthews, Z. E. (1954). J. Pediat., 44, 357.

King, A. J. (1954). British Journal of Venereal Diseases, 30, 13.

Kitchen, D. K., Rein, C. R., Thomas, E. W., and Spoor, H. J. (1951). Amer. J. Syph., 35, 578.

Kolmer, J. A. (1954). Ibid., 38, 176.

Leifer, W., and Martin, S. P. (1946). J. Amer. med. Ass., 130, 202.
Lepper, M. H., Rodriguez, J., Blatt, N., and Spies, H. W. (1952). Antibiot. and Chemother., 2, 175.

Levaditi, C., Penau, H., Vaisman, A., and Hagemann, G. (1949). Presse méd. 57, 356.

Liverpool School of Tropical Medicine (1943). " 44th Annual Report, 1942-1943", p. 4.

Lourie, E. M., and Collier, H. O. J. (1943). Ann. trop. Med. Parasit., 37, 200.

Lyons, F. Maxwell (1947). Bull. ophthal. Soc. Egypt, 40, 51.

Macchiavello, A., Omar, W., El Sayed, M. A., and Rahman, K. A. (1954). Bull. Wld Hith Org., 10, 1.

McElligott, G. L. M. (1953). In Z. Haut- u. GeschlKr., 15, 363, 394. Magnuson, H. J., and Eagle, H. (1945). Amer. J. Syph., 29, 587.

Mahoney, J. F., Arnold, R. C., and Harris, A. (1943). J. vener. Dis. Inform., 24, 355.

Marquez, F. Quoted by Rein and Mann, 1954.

Mayer, P. S., Mosko, M. M., Schutz, P. J., Osterman, F. A., Steen, L. H., and Baker, L. A. (1953). J. Amer. med. Ass., 151, 351 .

Nathanson, I. G., Morin, G. E., and Mallet, S. P. (1953). Antibiot. and Chemother., 3, 368.

O'Brien, J. F., and Smith, C. A. (1952). Amer. J. Syph., 36, 519.

Olansky, S., and Price, I. N. O. (1955). "The Modern Diagnosis of Syphilis" (In the press.)

Perry, C. B., and Gillespie, W. A. (1954). Brit. med. J., 2, 729.

Plotke, F., Eisenberg, H., Baker, A. H., and Laughlin, M. E. (1949). J. vener. Dis. Inform., 30, 252.

Pollitzer, R. (1954) "Plague", Monograph Series, No. 22, p. 462. W.H.O., Geneva.

Rein, C. R., Buckwalter, F. H., Mann, C. H., Landy, S. E., and Flax, S. (1953). J. invest. Derm., 21, 435. and Mann, C. H. (in collaboration with Ribas, E. B., Hill, K. R., Kroh, D. F., and Marquez, F.) (1954). An. brasil. Derm. Sif., 29, 157.

Ribas, E. B. Quoted by Rein and Mann (1954).

Schamberg, I. L. (1953). Quoted by Rein and others (1953). J. invest. Derm., 21, 435.

Schimmel, N. H., Wilson, W. W., Matteucci, W. V., and Flippin, H. F. (1952). Amer. J. med. Sci., 224, 247.

Seal, J. R., Weber, R. W., Goerner, R. T., Curtis, C. E., Frank, P. F., Levinson, M. L., Woolridge, R. L., and Crawford, Y. E. (1953). In "Antibiotics Annual. 1953-1954" (Proceedings of the Symposium on Antibiotics, October 28, 29, and 30, 1953, Washington, D.C.), p. 123. Medical Encyclopedia Inc., New York.

Seifter, J., Glassman, J. M., Begany, A. J., Ehrich, W. E., and Beckfield, W. J. (1954). Antibiot. and Chemother., 4, 633.

Shafer, J. K., and Smith, C. A. (1954). Bull. Wld Hlth Org., 10, 619. Siegal, S., Steinhardt, R. W., and Gerber, R. (1953). J. Allergy, 24, 1.

Smith, C. A., Cutler, J. C., and Price, E. V. (1954a). " Penicillin Reactions in a Venereal Disease Clinic Population." Paper presented at the Antibiotics Symposium, Washington, D.C., October, 1954.

O'Brien, J. F., Simpson, W. G., Harb, F. W., and Shafer, J. K. (1954b). Amer. J. Syph., 38, 136.

Stollerman, G. H., and Rusoff, J. H. (1952). J. Amer. med. Ass., $150,1571$.

Stroud, G. M. (1952). Arch. Derm. Syph. (Chicago), 66, 491.

Szabo, J. L., Edwards, C. D., and Bruce, W. F. (1951). Antibiot. and Chemother., 1, 499.

Tidwell, R. A. (1954). Northw. med. (Seattle), 53, 470.

Venereal-Disease-Control Manual of Maryland State (1954).

Vilanova, X., and Alvarado, L. (1954). Bull. Soc. frànc. Derm. Syph., 61, 356.

Waldbott, G. L. (1949). J. Amer. med. Ass., 139, 526.

Walker, I. C., and Hamburger, M. (1954). Antibiot. and Chemother., 4, 76.

Walker, S. H. (1954). J. Pediat., 44, 50.

Weiss, P. J., and Wright, W. W. (1953). Antibiot. and Chemother., 3, 1154.

Welch, H., Lewis, C. N., Kerlan, I., and Putnam, L. E. (1953). Ibid., 3, 891.

Willcox, R. R. (1954). British Journal of Venereal Diseases, 30, 7.

-, Guthe, T., Idsoe, O., and Reynolds, F. W. (1954). Amer. J. Syph., 38, 388. 